Article

\title{
Characterizing Physical and Social Compositions of Cities to Inform Climate Adaptation: Case Studies in Germany
}

\author{
Angela Wendnagel-Beck ${ }^{1, *}$, Marvin Ravan ${ }^{1}$, Nimra lqbal ${ }^{1}$, Jörn Birkmann ${ }^{1}$, Giorgos Somarakis ${ }^{2}$, \\ Denise Hertwig $^{3}$, Nektarios Chrysoulakis ${ }^{2}$ and Sue Grimmond ${ }^{3}$ \\ ${ }^{1}$ Institute of Spatial and Regional Planning, University of Stuttgart, Germany; \\ E-Mails: angela.wendnagel-beck@ireus.uni-stuttgart.de (A.W.-B.), marvin.ravan@ireus.uni-stuttgart.de (M.R.), \\ nimra.iqbal@ireus.uni-stuttgart.de (N.I.), joern.birkmann@ireus.uni-stuttgart.de (J.B.) \\ ${ }^{2}$ Remote Sensing Lab, Foundation for Research and Technology-Hellas Institute of Applied and Computational \\ Mathematics, Greece; E-Mails: somarage@iacm.forth.gr (G.S.), zedd2@iacm.forth.gr (N.C.) \\ ${ }^{3}$ Department of Meteorology, University of Reading, UK; E-Mails: d.hertwig@reading.ac.uk (D.H.), \\ c.s.grimmond@reading.ac.uk (S.G.) \\ * Corresponding author
}

Submitted: 14 May 2021 | Accepted: 7 August 2021 | Published: 16 December 2021

\begin{abstract}
Cities are key to climate change mitigation and adaptation in an increasingly urbanized world. As climate, socio-economic, and physical compositions of cities are constantly changing, these need to be considered in their urban climate adaptation. To identify these changes, urban systems can be characterized by physical, functional, and social indicators. Multi-dimensional approaches are needed to capture changes of city form and function, including patterns of mobility, land use, land cover, economic activities, and human behaviour. In this article, we examine how urban structure types provide one way to differentiate cities in general and to what extent socio-economic criteria have been considered regarding the characterization of urban typologies. In addition, we analyse how urban structure types are used in local adaptation strategies and plans to derive recommendations and concrete targets for climate adaptation. To do this, we examine indicators, background data used, and cartographic information developed for and within such urban adaptation plans, focusing in particular on the German cities of Karlsruhe and Berlin. The comparative analysis provides new insights into how present adaptation plans consider physical and social structures, including issues of human vulnerability within cities. Based on the analysis we make recommendations on how to improve the consideration of both physical and socio-economic aspects of a city to support pathways for adaptation.
\end{abstract}

\section{Keywords}

city typologies; climate adaptation; Germany; physical structures; socio-economic structures; urban indicators; vulnerability assessment

Issue

This article is part of the issue "Planning for the Local Impacts of Climate Change: Nobody Left Behind?" edited by Mark Seasons (University of Waterloo, Canada).

(C) 2021 by the authors; licensee Cogitatio (Lisbon, Portugal). This article is licensed under a Creative Commons Attribution 4.0 International License (CC BY).

\section{Introduction}

In the context of climate change, cities play a dual role: They accelerate climate change through increased greenhouse gas emissions and are places particularly affected by climate change (e.g., heat stress and flash floods; Rößler et al., 2014). To ensure a high quality of living for urban residents in a changing climate, adaptation measures have to be implemented at different spatial scales (Rößler et al., 2014). Urban planning can contribute to climate change mitigation through, for example, compact settlement forms, infrastructure that supports sustainable mobility and lifestyles, or resilience measures (e.g., nature-based solutions; Somarakis et al., 2019; Wende 
et al., 2010). Adaptation to the effects of climate change is an important challenge for spatial and urban planning. Future planning approaches must assess and consider a range of impacts on environment, society, and economy. Adverse societal impacts of climate change are significantly impacted by exposure and vulnerability of different population groups or settlement types and infrastructures (see Intergovernmental Panel on Climate Change [IPCC], 2012). Temperature rise, the apparent shift of the distribution of precipitation from summer to winter, and the increase in frequency of extreme events (e.g., heavy rain and heat waves) are expected to intensify further, based on current projections (IPCC, 2018). Socioeconomic development and physical changes of cities and regions modify exposure and vulnerability patterns (Birkmann et al., 2013). To assess vulnerability of urban residents to different impacts of climate change, multiple physical and socio-economic indicators that are also relevant for planning strategies need to be considered (Kappes et al., 2012; Li et al., 2016).

Cities are often subdivided into spatial units with similar physical conditions (e.g., building types, transport access, types of open space, and functionality). In some cases, socio-economic structures also are considered, such as residents' ages, income, and access to services. Because of their specific characteristics, each urban structure type may be affected differently by climate change and weather events (Beermann et al., 2013). Building typologies can influence exposure and vulnerability to different weather and climate related events, such as heat stress (IPCC, 2014). For example, in single-family houses with large gardens, air conditioning, and vegetation that provides shade, people may be less exposed to heat compared to multi-family homes in densely populated inner-city areas without these cooling potentials. Consequently, considering current and future characteristics of physical and social structures in cities, including different urban typologies within cities and their dynamics, is important for adaptation planning. Present adaptation strategies in cities in Germany consider different urban structure typologies for their formulation of adaptation needs and adaptation goals.

In this article, we investigate existing climate change adaptation plans for urban development and planning in two German cities-Berlin and Karlsruhe. These case study cities are used to examine (a) how different urban areas are characterized for adaptation in urban planning, and (b) how typologies within these strategies and plans differentiate physical and socio-economic structures that are relevant to identifying adaptation needs and climate resilient development.

\section{Conceptual Framework}

\subsection{Climate Vulnerability and Adaptation}

It is widely acknowledged, in addition to mitigation strategies, that adaptation strategies are essential to proactively manage future risks and to reduce or even prevent adverse consequences of climate change for societies and cities (Birkmann, 2013; IPCC, 2012, 2014; Mertz et al., 2009). There is emerging consensus that next to hazard or climate information, the differential vulnerability of people and infrastructure exposure needs to be assessed to develop a more comprehensive information basis for adaptation (Birkmann, 2013; Ford et al., 2018; IPCC, 2014). The strong interest from different disciplines on concepts of vulnerability and the multi-dimensional nature of vulnerability (e.g., physical, social, and economic) has led to different definitions, approaches, and methods across disciplines. Taking into account the existing variety of approaches to assess vulnerability (e.g., Bogardi \& Birkmann, 2004; Carreño et al., 2007; Füssel \& Klein, 2006; IPCC, 2012; Turner et al., 2003; Wisner et al., 2004), we build on this literature and use the definition of vulnerability developed within the context of recent IPCC $(2012,2014,2018)$ reports by researchers from both climate change research and disaster risk reduction.

In this context, vulnerability is defined as "the propensity or predisposition to be adversely affected" (IPCC, 2018, p. 560). Climate vulnerability may incorporate components including sensitivity or susceptibility to harm, but also response capacities, such as the lack of capacity to cope and adapt (Birkmann, 2013; IPCC, 2012). Considered this way, vulnerability does not solely focus on the fragility or susceptibility of a community, population group, or infrastructure, but also considers capacities to deal with and to adapt to shocks and hazards. Other approaches examine the vulnerability of ecosystems or capture and assess the vulnerability of coupled social-ecological systems (Bennett et al., 2016; Burton et al., 2002; Ford et al., 2018; O'Brien et al., 2007).

Therefore, the operationalization of vulnerability is a challenge, since it needs to measure and reflect social structures and societal development processes as well as material outcomes within systems that appear highly complex and are characterized by interdependencies that are difficult to capture (Adger, 2006). However, assessing vulnerability is an essential element to understand risks and to highlight the importance of social factors and societal structures in the construction of risk and the identification of adaptation options (Birkmann, 2013). Information about climatic hazards and physical structures within cities needs to be complemented with information about human vulnerability and respective socio-economic drivers of vulnerability to support urban adaptation planning. Hence, the analysis of urban typologies used within present adaptation strategies is an important research task to better understand what type of factors are, or are not, currently considered.

The term "urban structure types," Stadtstrukturtypen in German, was established in the 1990s to categorize different urban settlements. Since then, this concept has been used in planning and monitoring of cities and settlements (Novack \& Stilla, 2014). Mapping urban 
structure types allows differentiation of the urban system into distinct areas that include various configurations of built, open spaces, green spaces, and infrastructure (Heiden et al., 2012). To ensure these typologies can effectively inform future climate adaptation policies, an integrated approach that incorporates the physical and socio-economic characteristics of a city is needed. In this article, we examine whether and how such socioeconomic aspects and profiles are linked to settlement types/structures used in present approaches. In addition, we explore how these typologies could be strengthened to also include aspects of human vulnerability.

To aid development of a more integrated approach encompassing multiple dimensions of urban development, indicator-based methods provide a useful tool as they reduce complexity and allow a systematic operationalization and monitoring of the various aspects through time (Chrysoulakis et al., 2021). Indicators in ecology and environmental planning are used to depict and evaluate environmental conditions or changes (Heink \& Kowarik, 2010). To assess climate vulnerability and adaptive capacities, different sets of indicators have been developed (e.g., Birkmann, 2013; Chrysoulakis et al., 2014; He et al., 2019; Parsons et al., 2016; Wolf \& McGregor, 2013). However, it is important to note that indicator-based approaches regarding vulnerability also have limitations and are criticized because of uncertainties and data limitations (see, e.g., Turner et al., 2003). In many studies, aspects of economic vulnerability are represented with "conventional" economic indicators; at the same time, social vulnerability also often encompasses intangible factors that are difficult to quantify and validate (Sorg et al., 2018). There are numerous other indicator systems that are used in closely cognate urban disciplines and applications (e.g., consideration of green infrastructure cost and benefits in cities for various environmental services; Grimmond \& Souch, 1994; McPherson et al., 1997). However, in this article we focus particularly on the indicators used within existing urban adaptation concepts in two cities. Furthermore, we highlight the importance of other indicators that could provide further information about societal vulnerability at the household or settlement structure scale, such as household composition, age, education, income, and employment.

\subsection{Typologies of Urban Structure}

In general, typologies are both analytical and descriptive tools for developing and refining ideas, creating categorical classification, and sorting various case studies (Collier et al., 2012). In urban planning and architecture, recent examples include typologies that aim to provide historical narratives, reflect the urbanization process, categorize development trends, classify economic activities, and examine a wide range of environmental issues (Fragkias \& Seto, 2009; Kloosterman \& Lambregts, 2007; Li et al., 2020; Nijman, 2007; Zhou et al., 2017).
One key-use is to identify parameters that allow variability across a city to be assessed. In climate change research, urban typologies can be broadly categorized into those that consider physical and socio-economic aspects (Solecki et al., 2015). Typologies of urban structure have also been used globally in an attempt to categorize cities in the context of climate adaptation (Hrabovszky-Horváth et al., 2013; Salas \& Yepes, 2018; Storch \& Schmidt, 2008).

There are several ways through which planners, sociologists, geographers, economists, and environmentalists have attempted to define the physical and social structure of cities (including the economic, political, cultural, and institutional characteristics of the society). According to Wilson (2010, p. 201), "social structure refers to the way social positions, social roles, and networks of social relationships are arranged in our institutions, such as the economy, polity, education, and the organization of the households." There is increasing evidence that socio-economic urban structure is a centraldriving consideration in global environmental research and climate change studies (Banzhaf \& Hofer, 2008; Crenshaw \& Jenkins, 1996).

Physical urban structure mostly corresponds to spatial configuration of various structural elements of the built environment (Roca Cladera et al., 2009). Implicitly, physical/spatial structure includes "the characteristics of urban form and structure, as well as spatial configurations of structural elements, which can influence ecological functioning and human well-being in cities" (Larondelle et al., 2014, p. 427).

Overall, urban structure types are an important method and entry point for the analysis of intra-urban variations, both in terms of physical as well as social structures and dynamics. Urban structure types can be categorized with a variety of indicators which are used to quantify and measure different societal structures and specific dynamics. Table 1 provides an overview of indicators used to assess physical, socio-physical, and socio-economic structures and typologies in cities. These indicators range from capturing urban form, to featuring spatial configurations of different societal groups, integrating physical infrastructure to social infrastructure, and combining building typologies together with the household characteristics within an urban area.

\section{Methodology}

For this study we have undertaken an extensive literature review, assessing publications from multiple disciplines including urban planning, environmental planning, and social science, and examining physical and socio-economic indicators used to define and characterize "urban structure types" in adaptation research and applied in urban adaptation concepts. Both case study cities, Berlin and Karlsruhe, have published urban adaptation plans that use urban structure typologies. For these case studies, adaptation plans, project articles/reports, 
Table 1. Examples of indicators used to characterize social and physical structures of cities.

\begin{tabular}{|c|c|c|}
\hline Indicator & Component & Example references \\
\hline \multicolumn{3}{|l|}{ (a) Physical } \\
\hline $\begin{array}{l}\text { Land use/ } \\
\text { land cover }\end{array}$ & $\begin{array}{l}\text { Functional building use } \\
\text { Green spaces/open/public spaces } \\
\text { Road transport infrastructure }\end{array}$ & Nguyen et al. (2014); Xu et al. (2019) \\
\hline Building typology & $\begin{array}{l}\text { Morphology (e.g., footprint, height, building } \\
\text { density, arrangement) }\end{array}$ & $\begin{array}{l}\text { Hrabovszky-Horváth et al. (2013); } \\
\text { Kappes et al. (2012); Lowry and Lowry (2014) }\end{array}$ \\
\hline Density & $\begin{array}{l}\text { Population density (pop./ } / \mathrm{km}^{2} \text { ) } \\
\text { Average household size (people/housing unit) }\end{array}$ & $\begin{array}{l}\text { Galster et al. (2001); Kappes et al. (2012); } \\
\text { Torrens and Marina (2000) } \\
\text { Kappes et al. (2012); Song and Knaap (2004) }\end{array}$ \\
\hline \multicolumn{3}{|c|}{ (b) Physical-socio-economic } \\
\hline Centrality & Mean distance to social infrastructure (m) & $\begin{array}{l}\text { Galster et al. (2001); Song and Knaap (2004); } \\
\text { Theobald (2001) }\end{array}$ \\
\hline Accessibility & $\begin{array}{l}\text { Street connectivity (ratio streets to intersections) } \\
\text { Median perimeter of residential blocks }(\mathrm{m})\end{array}$ & $\begin{array}{l}\text { Song and Knaap (2004); Weston (2002) } \\
\text { Song and Knaap (2004); Weston (2002) }\end{array}$ \\
\hline Neighborhood mix & $\begin{array}{l}\text { Land use contiguity (Juxtapose Interspersion Index) } \\
\text { Land use richness (Patch Richness) } \\
\text { Land use diversity (Simpsons Diversity Index) }\end{array}$ & $\begin{array}{l}\text { Torrens and Marina (2000) } \\
\text { Frenkel and Ashkenazi (2008) } \\
\text { Frenkel and Ashkenazi (2008); Weston (2002) }\end{array}$ \\
\hline \multicolumn{3}{|l|}{ (c) Socio-economic } \\
\hline \multirow[t]{5}{*}{ Social } & Age distribution & $\begin{array}{l}\text { Cutter et al. (2003); Hahn et al. (2009); } \\
\text { Scheuer et al. (2011); Song and } \\
\text { Knaap (2004); Sorg et al. (2018) }\end{array}$ \\
\hline & Gender ratio & Mustafa (2003); Yoon (2012) \\
\hline & Illiterate population (\%) & $\begin{array}{l}\text { Eakin and Bojórquez-Tapia (2008); } \\
\text { Hahn et al. (2009); Handayani et al. (2017) }\end{array}$ \\
\hline & Disabled Population (\%) & $\begin{array}{l}\text { Hahn et al. (2009); Panthi et al. (2016); } \\
\text { Sorg et al. (2018) }\end{array}$ \\
\hline & Ethnicity / migration background & $\begin{array}{l}\text { Cutter et al. (2003); Fekete (2009); } \\
\text { Sorg et al. (2018); Yoon (2012) }\end{array}$ \\
\hline \multirow[t]{5}{*}{ Economic } & Number of (un)employed & $\begin{array}{l}\text { Cutter et al. (2003); Hahn et al. (2009); } \\
\text { Yoon (2012) }\end{array}$ \\
\hline & Household income & $\begin{array}{l}\text { Cutter et al. (2003); Jamshed et al. (2020); } \\
\text { Shah et al. (2018) }\end{array}$ \\
\hline & Social capital and livelihood & $\begin{array}{l}\text { Eakin and Bojórquez-Tapia (2008); } \\
\text { Jamshed et al. (2020); Qaisrani et al. (2018) }\end{array}$ \\
\hline & Economic performance (sales, industry, etc.) & Cutter et al. (2003) \\
\hline & House ownership & $\begin{array}{l}\text { Burton (2010); Fatemi et al. (2017); } \\
\text { Lee (2014) }\end{array}$ \\
\hline \multirow[t]{4}{*}{$\begin{array}{l}\text { Infrastructure } \\
\text { and utilities }\end{array}$} & $\begin{array}{l}\text { Access to social facilities (hospitals, retirement } \\
\text { home, kindergarten) }\end{array}$ & $\begin{array}{l}\text { Mustafa (2003); Panthi et al. (2016); } \\
\text { Qaisrani et al. (2018); Shrivastava (2003); } \\
\text { Zhao and Chen (2015) }\end{array}$ \\
\hline & $\begin{array}{l}\text { Access to amenities (water supply, gas, } \\
\text { electricity) }\end{array}$ & $\begin{array}{l}\text { Islam et al. (2013); Qaisrani et al. (2018); } \\
\text { Zhao and Chen (2015) }\end{array}$ \\
\hline & Dilapidated buildings & Fekete (2009); Xu et al. (2019) \\
\hline & Hospital beds per capita & Leichenko et al. (2015) \\
\hline Technology & Access to internet & Fatemi et al. (2017); Yoon (2012) \\
\hline
\end{tabular}

Note: Indicator categories adapted from Lowry and Lowry (2014) and Malakar and Mishra (2016). 
and cartographic information are analysed (e.g., environmental atlas in Berlin; Senate Department for Urban Development and the Environment, 2016a). To verify core findings, expert interviews, for example with representatives of the Senate Department for Urban Development and Housing of the City of Berlin, were conducted. The analysis provides new insights on how these urban typologies consider physical and social aspects and also reveals gaps that should be addressed in the future. The following research questions were used to investigate the urban adaptation strategies in Berlin and Karlsruhe:

- How are "urban structure types" defined?

- Which indicators are used to differentiate urban structure types?

- To what extent have socio-economic and demographic indicators been integrated into this characterization?

- How do the different "urban structure typologies" inform adaptation strategies and measures?

\section{Case Studies: Berlin and Karlsruhe}

Large and medium-sized cities in Germany play a key role in climate adaptation. German cities are often characterized by a polycentric structure that provides important economic, social, and cultural functions for the residents and surrounding areas. However, these structures may be vulnerable to climate change due to: (a) concentration of vulnerable groups, (b) climate change combining both urban (e.g., urban heat island) and regional influences (e.g., heat waves; Founda \& Santamouris, 2017), (c) damage potential, (d) high dependency on infrastructure services that might collapse in extreme events, and (e) adaptive capacity.

The city of Berlin has experienced significant heat stress from increasing regional temperatures exacerbated by the urban heat island effect (Behrens \& Grätz, 2010). The German Weather Service and the Senate for Urban Development's analysis of mean annual air temperature found that it increased by $1^{\circ} \mathrm{C}$ between 1971 and 2000 and that the number of "tropical nights" (nocturnal air temperature above $20^{\circ} \mathrm{C}$ ) also increased, particularly in the inner city (Behrens \& Grätz, 2010). By 2050, the number of very hot days (maximum daytime temperature above $30^{\circ} \mathrm{C}$ ) in the dense inner-city areas will increase to 25 days per year (Senate Department for Urban Development and Housing, 2011). Given Berlin's continental location, the summertime heat is often associated with challenges posed by water scarcity (Federal Ministry for the Environment, Nature Conservation and Nuclear Safety, 2008).

The city of Karlsruhe has large impervious cover and summer air temperature in the city than can be $10^{\circ} \mathrm{C}$ warmer than the surroundings (Beermann et al., 2014). Located within the Upper Rhine Rift Valley, this is the warmest region in Germany. Karlsruhe is consid- ered to be a city with heat-related health risks, which are a key concern (Beermann et al., 2014). Considerable small-scale temperature differences occur within the various built-up areas, thus underlining the relevance of urban structure types, including the degree of sealing and green spaces (Hackenbruch, 2018).

\subsection{City of Berlin}

Climate adaptation and mitigation pose new challenges to sustainable urban development for the city of Berlin (Senate Department for Urban Development and Housing, 2011). On the one hand, these issues are relevant for the modification of existing urban structures (e.g., optimization of existing buildings, infrastructure, and green/open spaces). On the other hand, mitigation and adaptation issues need to be considered from the beginning when planning and implementing new urban areas. To improve the consideration of climate change adaptation and mitigation, Berlin has developed and approved a city climate development plan, which is updated occasionally (Senate Department for Urban Development and the Environment, 2016b). It examines spatially differentiated impacts of climate change in Berlin and identifies action for urban development. A core question addressed within the urban climate development plan is the following: How can Berlin strengthen its urban sustainability and resilience within a changing climate, focusing on citizens and infrastructure? (Senate Department for Urban Development and Housing, 2011). Special emphasis is given to heat stress and heavy precipitation events as these are hazards that may be critical in future climates. In the next section, we examine the settlement and building typologies used within this urban development plan for climate adaptation.

\subsubsection{Typologies}

The Senate Department for Urban Development and Environment developed an environmental atlas that classifies the city based on urban structure types. These are defined by their building structure and density, open spaces, and representative land use and building use typologies (e.g., industrial versus residential use). Grimmond (2007) and Hertwig et al. (2021) underscore that neighbourhood structure, built volume, and people's behaviour significantly modify the local urban climate (e.g., local air temperature, wind speed). Different neighbourhood compositions or archetypes will influence the adaptation measures that are needed or feasible (Ward \& Grimmond, 2017). Against this background it is interesting to note that the environmental atlas for Berlin encompasses 52 area-types grouped into 16 settlement-structure types and six main groups (Senate Department for Urban Development and the Environment, 2016a). The main groups are: 
- Group I: Dense residential development;

- Group II: Low-density residential development;

- Group III: Commercial, service use, small business, and industrial use;

- Group IV: Traffic areas;

- Group V: Public service and other special uses;

- Group VI: Green and open spaces.

The purpose of these types is to further differentiate the built areas, particularly to inform urban and environmental planning. Residential areas, for example, are further differentiated by indicators such as building density, height, and age within the classification used by the Senate (Senate Department for Urban Development and the Environment, 2016a).

\subsubsection{Climate Adaptation in Urban Planning}

Urban planning at city scale aims to define and implement broad and strategic development goals for the entire city. Hence, adaptation measures to strengthen the resilience in terms of climatic hazards have to consider the broader urban development goals, including issues of mitigation and the provision of housing for a growing population. The provision of green spaces and the protection of urban biodiversity are seen as important overall goals for urban development (Senate Department for Urban Development and the Environment, 2016a).

Berlin's climate adaptation plan defines adaptation measures for different settlement typologies. The adaptation plan makes use of five different structures and two area types (of the 52 area and 16 urban-structure types) of the environmental atlas to define adaptation needs (Senate Department for Urban Development and the Environment, 2016b). These typologies are:

- Compact perimeter block development;

- Re-densification of row houses;

- New apartment buildings;

- Commercial and industrial buildings;

- Infrastructure/schools;

- Streets and squares;

- Green and open spaces.

These classifications are used to distinguish adaptation needs, since these settlement typologies refer to areas that are: (a) already exposed to climatic stress today and/or particularly high stress is expected in the future, (b) undergoing (or expected to undergo) extensive changes, such as new construction and densification, (c) relatively homogeneous and therefore suggested measures are transferrable (no special cases), and (d) relevant for the entire city and cover a high proportion of the urban landscape as a whole (Senate Department for Urban Development and the Environment, 2016b).

The climate adaptation plan of Berlin primarily focuses on residential areas. The first two structure types (i.e., perimeter block development and town houses) are indicative of the proposed adaptation planning strategies of re-densification. Schools and technology parks are infrastructures with important functions extending beyond their specific ward (Senate Department for Urban Development and the Environment, 2016b).

To examine how the structure types are used to frame adaptation strategies and measures within Berlin, we selected the compact perimeter block development (Figure 1) as an example. About $15 \%$ of the residential housing is from the Wilhelminian Period (1890-1918), covering around $8 \%$ of the total area of Berlin (approximately 3,880 ha). This structure type is more common in inner-city districts (e.g., $65 \%$ of Mitte, $73 \%$ of Friedrichshain-Kreuzberg, 37\% of CharlottenburgWilmersdorf districts; Senate Department for Urban Development and Housing, 2011). About 36\% of Berlin's population (more than 1.2 million people) resides in perimeter blocks (Reusswig et al., 2014). These are largely dense areas, with limited access to green space and heterogeneous ownership patterns. With more frequent heat stress, these areas are likely to be affected, due to the relatively high density (exposure) and the limited adaptive capacity (e.g., access to green spaces). The urban adaptation plan suggests measures (Figure 1) focused on improving green infrastructure (e.g., greening façades, development of small parks) and increasing roof albedo to decrease short-wave radiation absorption (Senate Department for Urban Development and the Environment, 2016b). The proposed adaptation measures and goals in the urban adaptation plan for Berlin are closely coupled with selected settlement typologies used to characterize adaptation needs.

\subsection{City of Karlsruhe}

The development of an urban adaptation plan for Karlsruhe was triggered by the lack of a city-wide overview of where the city quarters most affected by heat stress were located (Beermann et al., 2013). The urban climate adaptation plan had two main phases of development and the formulation of adaptation measures. First, the plan identified and defined specific urban structure types according to their physical structure and aspects of stability and dynamics. Second, climate change "hot spots" were identified by assessing the structure types and their susceptibility to weather extremes and other important factors (e.g., demographic composition and access to green space). Using urban structure types aids transferability of adaptation measures across the city when the physical and social structures are brought together. This should help identification of locations of concern not yet exposed to heat stress (Beermann et al., 2013).

\subsubsection{Typologies}

Karlsruhe classified all of its 556 neighbourhoods (in German, Stadtviertel) into one of the 12 identified urban 


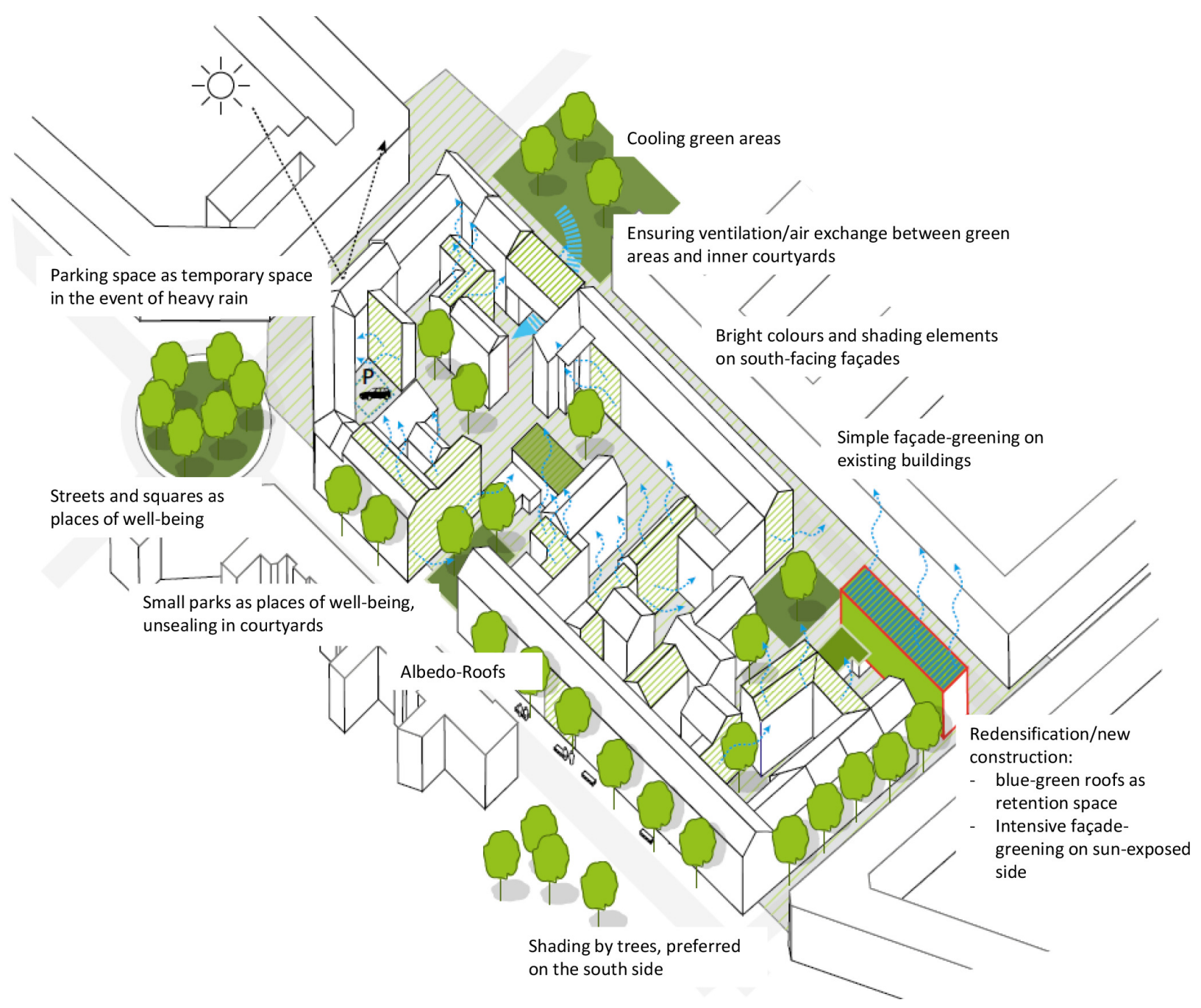

Figure 1. Potential adaptation measure for a compact perimeter block development proposed in the urban development plan. Source: Authors' work adapted from Senate Department for Urban Development and the Environment (2016b).

structure types (Figure 2). A multi-criteria analysis combined the structural characteristics of the neighbourhood with human and societal characteristics, with the latter giving some hints on aspects of human vulnerability (Section 4.2.2). The urban adaptation strategy anticipates that nine of the 12 structure types will require adaptation measures by 2050 because of their relatively high vulnerability metrics (Beermann et al., 2014). The structure types are grouped into three classes (Table 2): medium to high climatic stress, low to no climatic stress, and low exposure to heat stress. These refer to different levels of concern and demonstrate differential adaptation needs to climatic hazards.

\subsubsection{Climate Adaptation in Urban Planning}

The identification of adaptation needs for specific neighbourhoods and settlement typologies in Karlsruhe also consider future changes, particularly: (a) high level of local climatic stress (e.g., heat stress) at present or in the near future (2046-2055); (b) sensitive land and building use in the area; (c) high population density (more than 250 inhabitants $/ \mathrm{km}^{2}$ ); (d) high proportion of young children (less than four years of age), elderly people (65 or more years of age), and people living in one-person households; (e) no green space within walking distance; and (f) low energy efficiency of buildings in the area (Beermann et al., 2013, 2014).

The criteria include physical characteristics of the urban structure, but also aspects of human exposure and human vulnerability. Identification of hot spots and their adaptation measures within the urban structure adaptation measures are proposed for row development (Figure 3), which have these characteristics (Beermann et al., 2013):

- Four parallel six-floor residential buildings (age band: 1950s to 1960s);

- Population density of approximately 200 inhabitants/ha;

- Little vegetation around the buildings;

- Few publicly accessible green areas within $500 \mathrm{~m}$ that can provide shade or cooler area;

- Low energy standard of buildings; 


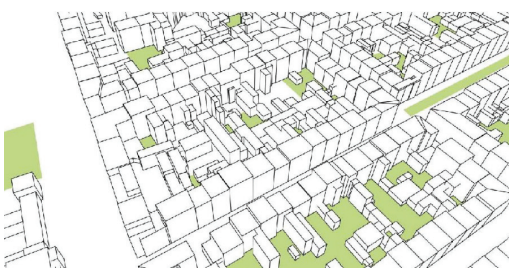

Closed perimeter block development

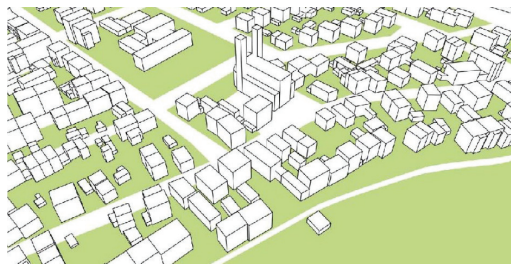

Town centre

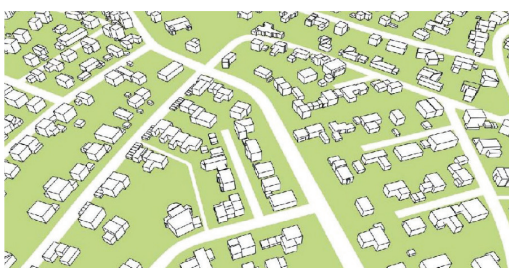

Low-density development

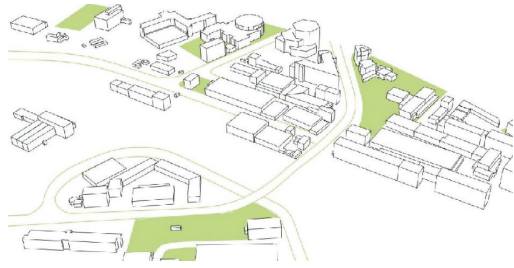

Commerce

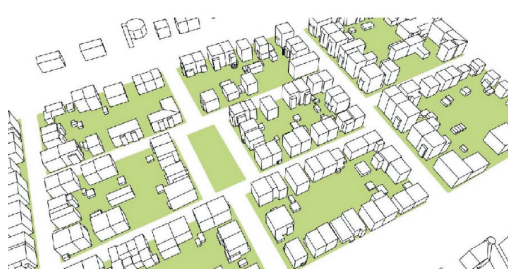

Open perimeter block development

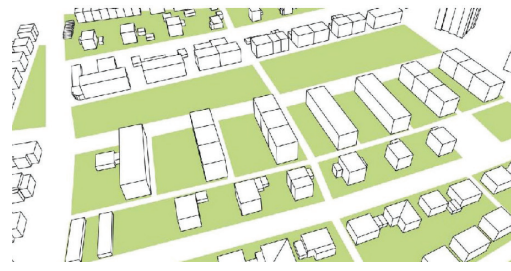

Medium-density development

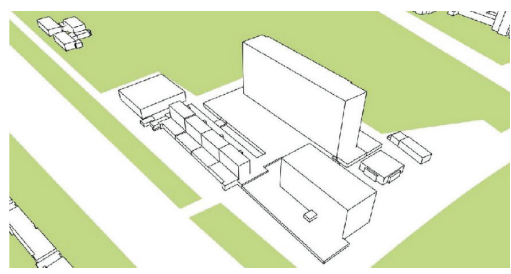

High-rise area (predominantly residential use)

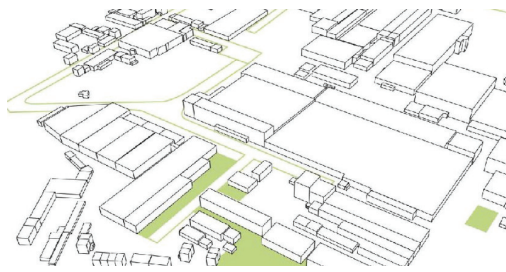

Industry

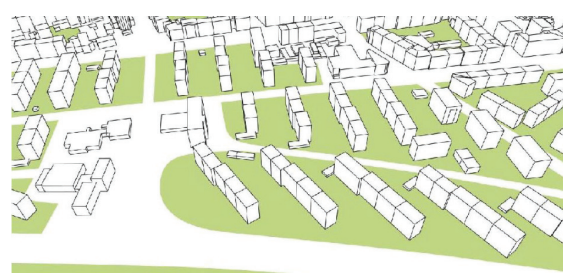

Row development

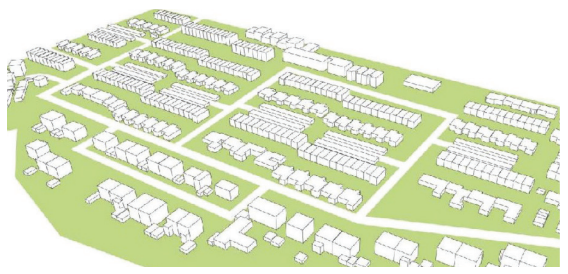

Compact detached houses

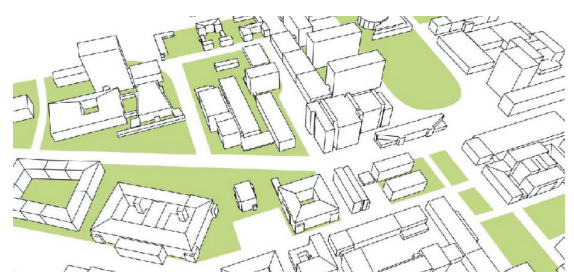

Areas with large structures

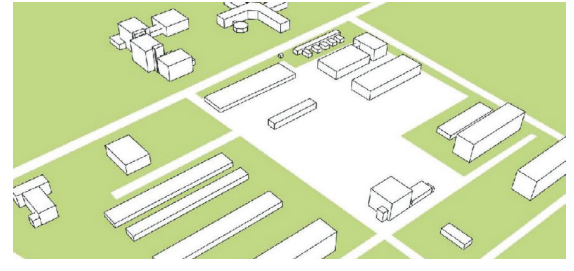

Special area

Figure 2. Major urban structure types in Karlsruhe. Source: Authors' work adapted from Beermann et al. (2013).

Table 2. Structure type classes (Figure 2) in Karlsruhe are distributed across 556 neighbourhoods (Stadtviertel) with different levels of concern with respect to climatic stress now (2010) and in 2050.

\begin{tabular}{lccr}
\hline Structure type class & Neighbourhoods & 2010 & 2050 \\
\hline Medium to high climatic stress & & & \\
Closed perimeter block development & 47 & 32 & 45 \\
Industrial & 13 & 6 & 10 \\
Commerce & 69 & One historic centre & 53 \\
Town centre & 19 & & 1 \\
& & & \\
Low to no climatic stress & 45 & 0 & 3 \\
Medium-density development & 41 & 3 & 16 \\
Areas with large structures & 86 & 2 & 11 \\
Row development & 25 & 3 & 8 \\
High-rise area & & & 0 \\
Low exposure to heat stress (not a priority for adaptationts) & \\
Compact detached houses & & & \\
Low-density development & 64 & 0 & 1 \\
Open perimeter block development & 116 & 0 & 150 \\
Special area & 26 & 0 & 0 \\
Karlsruhe (whole city) & 5 & & \\
\hline
\end{tabular}


- Proportion of senior citizens of $14.6 \%$;

- Proportion of young children of $5.7 \%$.

It is assumed that these areas already are significantly affected by heat stress (about 50 days per year) and expected to increase ( 58 days of heat stress and 10 days of tropical nights per year) by 2050 (Beermann et al., 2014). Urban structure types are identified as being a hot spot if neighbourhood vulnerability is classified as high due to its population structure and composition (Beermann et al., 2014). Adaptation measures to improve the resilience in a specific neighbourhood (Figure 3 ) of this type include adding pocket parks, improving or providing blue (water) infrastructure in public spaces, and reducing impervious areas. In addition to these physical measures, the adaptation concept also
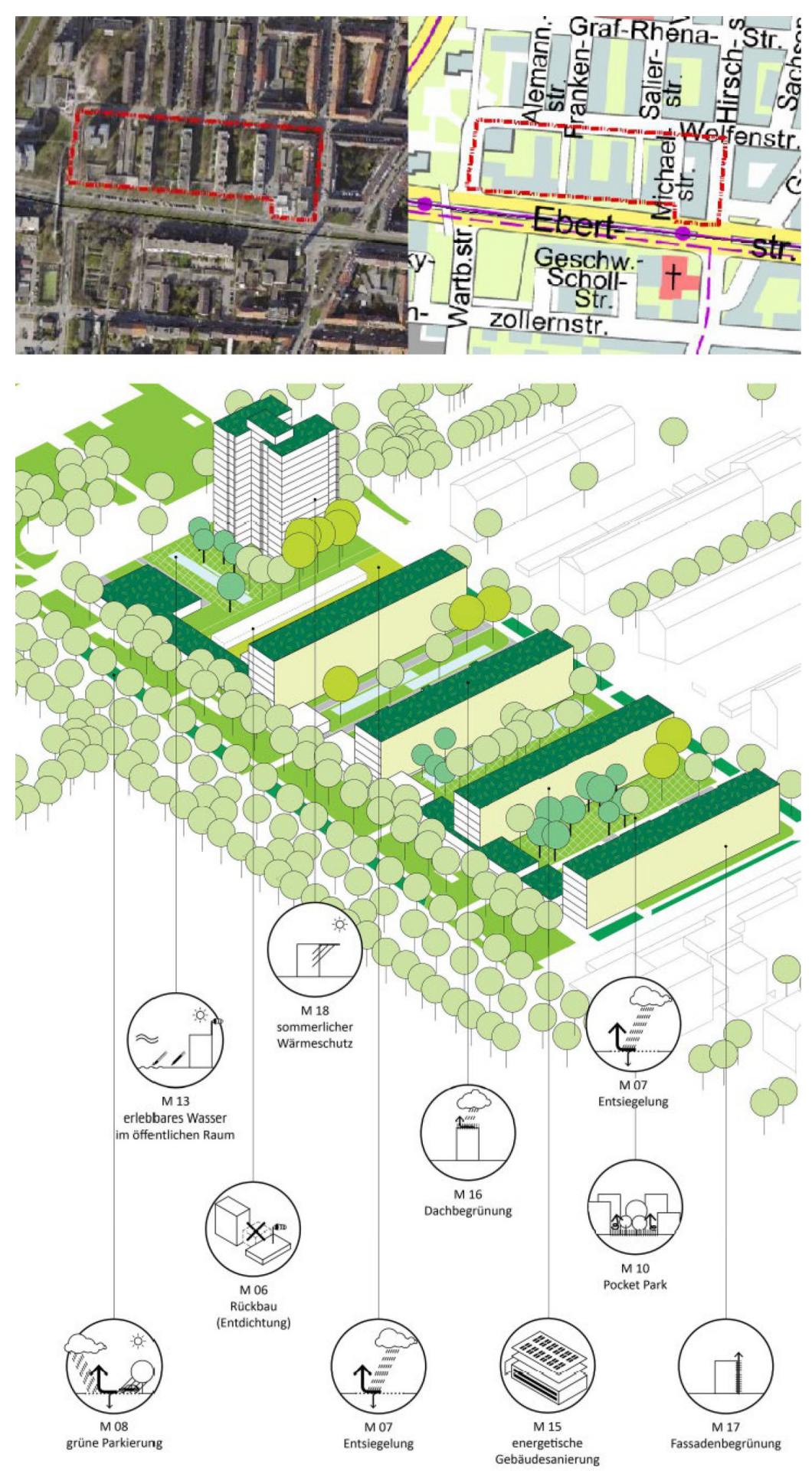

Figure 3. Proposed adaptive modifications for a neighbourhood with the row development (Figure 2) structure type in Karlsruhe. Source: Authors' work adapted from Beermann et al. (2014). 
focuses on reducing human vulnerability (e.g., reducing isolation of elderly residents). Lastly, the adaptation plan suggests improving the energy efficiency of buildings and modification of building thermal properties (e.g., greening walls) to improve both adaptation and mitigation. The proposed adaptation strategies and actions need to: (a) consider the specific conditions in each neighbourhood, (b) promote vulnerability reduction of residents exposed, and (c) support adaptation measures appropriate for transfer to other areas with the same structure type (Beermann et al., 2013).

Overall, the city of Karlsruhe proposed 19 adaptation measures for different structure types focusing on three spatial scales of intervention: city, neighbourhood, and building (Beermann et al., 2014).

\section{Discussion}

The comparative analysis of the urban adaptation strategies linked to urban development and planning in Berlin and Karlsruhe shows that urban structure typologies are an important entry point for these cities to identify adaptation needs and measures. The two cities use various indicators (Table 3 ) within their definition of urban structure types. While the physical indicators used to characterize urban form are similar, the characterization of social aspects and use of social indicators differ. Although both use social indicators to identify hot spots and, in part, adaptation measures, they differ in the criteria they use for identifying specific adaptation measures (Table 3). Both cities use land cover characteristics, building typologies, population density, and the availability of green spaces to identify adaptation needs along different settlement typologies. While Berlin uses more detailed criteria (e.g., related to impervious area), Karlsruhe focuses more on the access to pervious (green) spaces.

In both cities, socio-economic indicators such as household income or unemployment are not explicitly integrated into the formulation and assessment of structure types. However, in Karlsruhe the proportion of young children (less than four years of age) and seniors living alone in specific neighbourhoods is part of the adaptation measures. Hence, Karlsruhe takes a more integrative approach to urban adaptation to climate change in terms of renewal and new urban development which includes goals and measures to safeguard a larger mix of different age groups within a ward and to avoid isolation of the elderly who are likely to be most vulnerable.

In Berlin, additional strategies and tools exist that account for differential human vulnerability, such as those related to health and civil protection (Reusswig et al., 2016). However, the urban typologies used do not sufficiently address these issues.

Table 3. Case study cities compared using material in Beermann et al. $(2013,2014)$ and Senate Department for Urban Development and the Environment (2016a, 2016b).

\begin{tabular}{|c|c|c|}
\hline & Berlin & Karlsruhe \\
\hline \multicolumn{3}{|c|}{ Indicators used to characterize urban structure types } \\
\hline Building year of construction & $\mathrm{Y}$ & Y \\
\hline Building height & Y & Y \\
\hline Building arrangement & Y & Y \\
\hline Building shape & - & Y \\
\hline Building use & $\mathrm{Y}$ & - \\
\hline Population density & Y & Y \\
\hline Degree of sealing & Y & - \\
\hline Open space characteristics & $\mathrm{Y}$ & $\mathrm{Y}$ \\
\hline Area and Green/Open space use & Y & - \\
\hline Access patterns & - & $\mathrm{Y}$ \\
\hline \multicolumn{3}{|c|}{ Criteria for selecting areas needing climate adaptation } \\
\hline Use & Intense & Sensitive \\
\hline Stress & Present and future climate & Bioclimate \\
\hline Land cover & Proportion of urban landscape & $\begin{array}{l}\text { Green areas accessible } \\
\text { Green area quality }\end{array}$ \\
\hline Population & - & $\begin{array}{c}\text { Density } \\
\text { Fraction: seniors ( } \geq 65 \text { years old), } \\
\text { children (<4 years old), } \\
\text { and seniors living alone }\end{array}$ \\
\hline Energy & - & Energy standard of buildings \\
\hline Transferability of measures & $\mathrm{Y}$ & Y \\
\hline
\end{tabular}

Note: Indicators used are identified with a Y (yes) or comments. 
Both cities use urban structure types to help identify intra-city variations and adaptation needs using similar procedures and definition of adaptation measures (Figure 4). First, urban structures are classified using physical indicators (Tables 1 and 3). Second, present and future climatic stress is assessed by structure type and adaptation needs formulated with some quantitative analyses. Third, adaptation measures are formulated for specific structure types and hot spots. Societal and social indicators are sometimes used (Figure 4 ) to further specify adaptation needs and measures. Societal indicators capture mostly aspects of demography and population density, but sometimes they also capture social isolation (e.g., elderly in Karlsruhe). A broader integration of socio-economic indicators covering the functions within these neighbourhoods is still missing (Table 1).

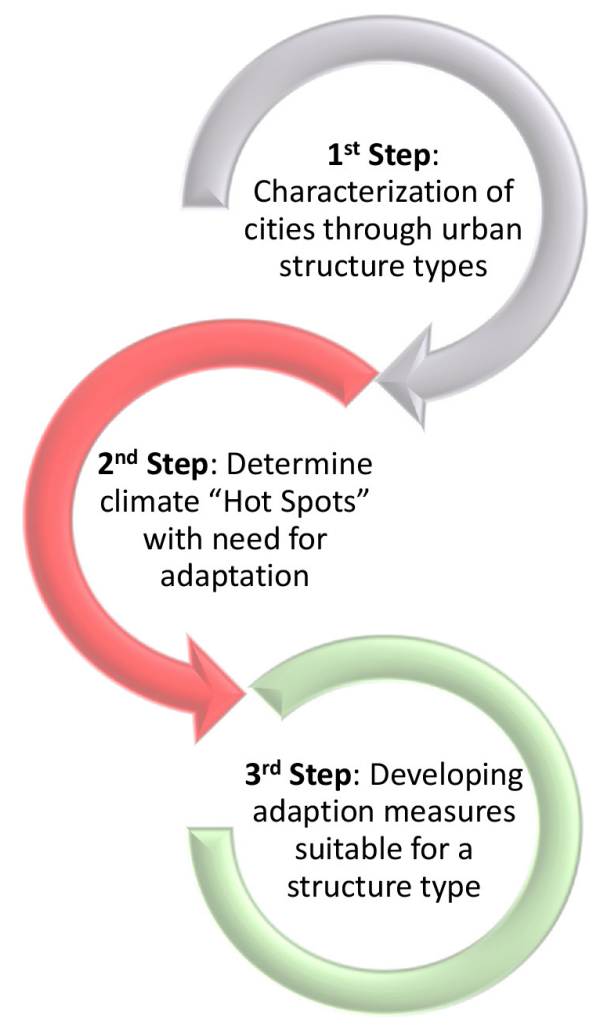

Figure 4. Planning sequence that is common in both case studies. Terms are defined in various places in the text.

In this regard, Capel-Timms et al. (2020) and Grimmond et al. (1996) underscore that socio-economic indicators are critical proxies of how neighbourhoods function and how humans interact with and affect the physical environment characteristics and dynamic behavioural patterns in each area (see also Grimmond \& Oke, 1986; Kokkonen et al., 2018; Quattrone \& Zannou, 1998; Ward \& Grimmond, 2017). Therefore, there is a co-dependence between the physical and the socio-economic environment (Banzhaf \& Hofer, 2008; Grimmond et al., 1996). Moreover, urban socio-economic structure is an essential driving force of urban climate change (Banzhaf \& Hofer, 2008; Crenshaw
\& Jenkins, 1996; Grimmond, 2007; Krellenberg et al., 2011). However, the urban adaptation plans in Berlin and Karlsruhe capture these broader aspects and neighbourhood functions only partially, if at all.

\section{Conclusion}

Analysis of urban adaptation strategies used in urban planning reveals that urban structure types play an important role in assessing climate risks and formulating adaptation needs and actions. The review of strategies and planning documents for Berlin and Karlsruhe underscores that within the definition of urban structure types, physical indicators play a key role, while less attention is given to social indicators, particularly socio-economic aspects. However, some social indicators are included in the adaptation measures developed for both cities. While most attention is paid to the physical structure of the respective urban typology, socio-demographic aspects also receive attention, but significantly less or at a later stage within the assessment. While Berlin emphasises improving the physical structures to better adapt to climate change (e.g., improving green spaces or reducing impervious area), Karlsruhe gives greater importance to societal indicators in its formulation of adaptation goals.

We see an urgent need to further strengthen urban adaptation concepts and link these to formal and informal tools of urban development that allow those responsible for climate adaptation to address both physical and social structures within the city. In addition, interactions between different neighbourhoods and functions, for example in terms of mobility and commuting patterns, are at present not sufficiently captured and should receive more attention in future urban adaptation plans.

Overall, an integrated approach considering both urban physical and social structures can better support and inform urban planning, urban development, and climate adaptation. More research is needed on how to enhance an integrative assessment that can link physical and social characteristics of urban areas. In this regard, constraints and limitations of linking physical and social structures need to be better understood. In addition, a more dynamic understanding of cities and their exposure and vulnerability to climatic hazards is needed. This requires, among other issues, new data and new methods for the identification and development of urban archetypes (societal driven settlement structure typology) that also capture the dynamics of behaviour (work, travel, recreation, etc.) and dynamics of urban development (migration, densification vs. urban sprawl, economic development trends, etc.).

\section{Acknowledgments}

This work is part of the urbisphere project (www. urbisphere.eu), a synergy project funded by the European Research Council (ERC-SyG) within the European Union's Horizon 2020 research and innovation 
programme under grant agreement no. 855005. The authors gratefully acknowledge helpful discussions with Jörn Welsch of Berlin's environmental atlas team and Elke Plate from the Senate Department for Urban Development and Housing of the City of Berlin.

\section{Conflict of Interests}

The authors declare no conflict of interests.

\section{References}

Adger, W. N. (2006). Vulnerability. Global Environmental Change, 16(3), 268-281.

Banzhaf, E., \& Hofer, R. (2008). Monitoring urban structure types as spatial indicators with CIR aerial photographs for a more effective urban environmental management. IEEE Journal of Selected Topics in Applied Earth Observations and Remote Sensing, 1(2), 129-138. https://doi.org/10.1109/JSTARS. 2008.2003310

Beermann, B., Berchthold, M., Baumüller, J., Gross, G., \& Kratz, M. (2013). Städtebaulicher Rahmenplan Klimaanpassung für die Stadt Karlsruhe (Teil I) [Urban framework plan for climate adaptation for the city of Karlsruhe (Part I)]. LUBW Landesanstalt für Umwelt, Messungen und Naturschutz Baden-Württemberg.

Beermann, B., Berchthold, M., Baumüller, J., Gross, G., \& Kratz, M. (2014). Städtebaulicher Rahmenplan Klimaanpassung für die Stadt Karlsruhe (Teil II) [Urban framework plan for climate adaptation for the city of Karlsruhe (Part II)]. LUBW Landesanstalt für Umwelt, Messungen und Naturschutz Baden-Württemberg.

Behrens, U., \& Grätz, A. (2010). Berlin im Klimawandel: Eine Untersuchung zum Bioklima [Berlin in the face of climate change: An investigation into the bioclimate]. Senate Department for Urban Development and Housing. https://www.stadtentwicklung. berlin.de/umwelt/umweltatlas/download/Berlin_ Waermebelastung_der_Zukunft_Projektbericht.pdf

Bennett, N. J., Blythe, J., Tyler, S., \& Ban, N. C. (2016). Communities and change in the anthropocene: Understanding social-ecological vulnerability and planning adaptations to multiple interacting exposures. Regional Environmental Change, 16, 907-926. https://doi.org/10.1007/s10113-015-0839-5

Birkmann, J. (2013). Measuring vulnerability to natural hazards: Towards disaster resilient societies. United Nations University Press.

Birkmann, J., Vollmer, M., \& Schanze, J. (2013). Raumentwicklung und Klimawandel-Herausforderungen für die räumliche Planung [Spatial development and climate change-Challenges for spatial planning]. Akademie für Raumentwicklung in der Leibniz-Gemeinschaft.

Bogardi, J., \& Birkmann, J. (2004). Vulnerability assessment: The first step towards sustainable risk reduction. In D. Malzahn \& T. Plapp (Eds.), Disaster and society: From hazard assessment to risk reduction (pp. 75-82). Logos Verlag.

Burton, C. G. (2010). Social vulnerability and hurricane impact modeling. Natural Hazards Review, 11(2), 58-68. https://doi.org/10.1061/(ASCE)15276988(2010)11:2(58)

Burton, I., Huq, S., Lim, B., Pilifosova, O., \& Schipper, E. L. (2002). From impacts assessment to adaptation priorities: The shaping of adaptation policy. Climate Policy, 2, 145-159.

Capel-Timms, I., Smith, S. T., Sun, T., \& Grimmond, S. (2020). Dynamic anthropogenic activities impacting heat emissions (DASH v1.0): Development and evaluation. Geoscientific Model Development, 13(10), 4891-4924. https://doi.org/10.5194/gmd-13-48912020

Carreño, M. L., Cardona, O. D., \& Barbat, A. H. (2007). Urban seismic risk evaluation: A holistic approach. Journal of Natural Hazards, 40(1), 137-172.

Chrysoulakis, N., Feigenwinter, C., Triantakonstantis, D., Penyevskiy, I., Tal, A., Parlow, E., Fleishman, G., Düzgün, S., Esch, T., \& Marconcini, M. (2014). A conceptual list of indicators for urban planning and management based on earth observation. ISPRS International Journal of Geo-Information, 3(3), 980-1002. https://doi.org/10.3390/ijgi3030980

Chrysoulakis, N., Somarakis, G., Stagakis, S., Mitraka, Z., Wong, M.-S., \& Ho, H.-C. (2021). Monitoring and evaluating nature-based solutions implementation in urban areas by means of earth observation. Remote Sensing, 13(8), Article 1503. https://doi.org/ $10.3390 / \mathrm{rs} 13081503$

Collier, D., LaPorte, J., \& Seawright, J. (2012). Putting typologies to work. Political Research Quarterly, 65(1), 217-232. https://doi.org/10.1177/10659129 12437162

Crenshaw, E. M., \& Jenkins, J. C. (1996). Social structure and global climate change: Sociological propositions concerning the greenhouse effect. Sociological Focus, 29(4), 341-358. https://doi.org/10.1080/ 00380237.1996.10570650

Cutter, S. L., Boruff, B. J., \& Lynn Shirley, W. (2003). Social vulnerability to environmental hazards. Social Science Quarterly, 84(2), 242-261. https://doi.org/ 10.1111/1540-6237.8402002

Eakin, H., \& Bojórquez-Tapia, L. A. (2008). Insights into the composition of household vulnerability from multicriteria decision analysis. Global Environmental Change, 18(1), 112-127. https://doi.org/10.1016/ j.gloenvcha.2007.09.001

Fatemi, F., Ardalan, A., Aguirre, B., Mansouri, N., \& Mohammadfam, I. (2017). Social vulnerability indicators in disasters: Findings from a systematic review. International Journal of Disaster Risk Reduction, 22, 219-227. https://doi.org/10.1016/j.ijdrr. 2016.09.006

Federal Ministry for the Environment, Nature Conservation and Nuclear Safety. (2008). Deutsche 
Anpassungsstrategie an den Klimawandel [German strategy for adaptation to climate change]. Die Bundesregierung. https://www.bmu.de/fileadmin/ bmu-import/files/pdfs/allgemein/application/pdf/ das_gesamt_bf.pdf

Fekete, A. (2009). Validation of a social vulnerability index in context to river-floods in Germany. Natural Hazards and Earth System Sciences, 9(2), 393-403. https://doi.org/10.5194/nhess-9-393-2009

Ford, J. D., Pearce, T., McDowell, G., Berrang-Ford, L., Sayles, J. S., \& Belfer, E. (2018). Vulnerability and its discontents: The past, present, and future of climate change vulnerability research. Climatic Change, 151(2), 189-203. https://doi.org/10.1007/ s10584-018-2304-1

Founda, D., \& Santamouris, M. (2017). Synergies between urban heat island and heat waves in Athens (Greece), during an extremely hot summer (2012). Scientific Reports, 7(1), Article 10973. https://doi. org/10.1038/s41598-017-11407-6

Fragkias, M., \& Seto, K. C. (2009). Evolving rank-size distributions of intra-metropolitan urban clusters in South China. Computers, Environment and Urban Systems, 33(3), 189-199. https://doi.org/10.1016/ j.compenvurbsys.2008.08.005

Frenkel, A., \& Ashkenazi, M. (2008). Measuring urban sprawl: How can we deal with it? Environment and Planning B: Planning and Design, 35(1), 56-79. https://doi.org/10.1068/b32155

Füssel, H. M., \& Klein, R. J. T. (2006). Climate change vulnerability assessments: An evolution of conceptual thinking. Climatic Change, 75(3), 301-329.

Galster, G., Hanson, R., Ratcliffe, M. R., Wolman, H., Coleman, S., \& Freihage, J. (2001). Wrestling sprawl to the ground: Defining and measuring an elusive concept. Housing Policy Debate, 12(4), 681-717. https:// doi.org/10.1080/10511482.2001.9521426

Grimmond, C. S. B., \& Oke, T. R. (1986). Urban water balance: 2. Results from a suburb of Vancouver, British Columbia. Water Resources Research, 22(10), 1404-1412. https://doi.org/10.1029/wr022i010p01 404

Grimmond, C. S. B., \& Souch, C. (1994). Surface description for urban climate studies: A GIS based methodology. Geocarto International, 9(1), 47-59. https:// doi.org/10.1080/10106049409354439

Grimmond, C., Souch, C., \& Hubble, M. (1996). Influence of tree cover on summertime surface energy balance fluxes, San Gabriel Valley, Los Angeles. Climate Research, 6, 45-57. https://doi.org/10.3354/ cr006045

Grimmond, S. (2007). Urbanization and global environmental change: Local effects of urban warming. The Geographical Journal, 173(1), 83-88. https://doi. org/10.1111/j.1475-4959.2007.232_3.x

Hackenbruch, J. (2018). Anpassungsrelevante Klimaänderungen für städtische Baustrukturen und Wohnquartiere [Adaptation-relevant climate changes for urban building structures and residential neighbourhoods]. KIT Scientific Publishing.

Hahn, M. B., Riederer, A. M., \& Foster, S. O. (2009). The livelihood vulnerability index: A pragmatic approach to assessing risks from climate variability and change-A case study in Mozambique. Global Environmental Change, 19(1), 74-88. https://doi. org/10.1016/j.gloenvcha.2008.11.002

Handayani, W., Rudiarto, I., Setyono, J. S., Chigbu, U. E., \& Sukmawati, A. M. (2017). Vulnerability assessment: A comparison of three different city sizes in the coastal area of Central Java, Indonesia. Advances in Climate Change Research, 8(4), 286-296. https://doi.org/ 10.1016/j.accre.2017.11.002

He, C., Zhou, L., Ma, W., \& Wang, Y. (2019). Spatial assessment of urban climate change vulnerability during different urbanization phases. Sustainability, 11(8), Article 2406. https://doi.org/10.3390/su11082406

Heiden, U., Heldens, W., Roessner, S., Segl, K., Esch, T., \& Mueller, A. (2012). Urban structure type characterization using hyperspectral remote sensing and height information. Landscape and Urban Planning, 105(4), 361-375. https://doi.org/10.1016/ j.landurbplan.2012.01.001

Heink, U., \& Kowarik, I. (2010). What are indicators? On the definition of indicators in ecology and environmental planning. Ecological Indicators, 10(3), 584-593. https://doi.org/10.1016/j.ecolind.2009.09. 009

Hertwig, D., Grimmond, S., Kotthaus, S., Vanderwel, C., Gough, H., Haeffelin, M., \& Robins, A. (2021). Variability of physical meteorology in urban areas at different scales: Implications for air quality. Faraday Discussions, 226, 149-172. https://doi.org/10.1039/ d0fd00098a

Hrabovszky-Horváth, S., Pálvölgyi, T., Csoknyai, T., \& Talamon, A. (2013). Generalized residential building typology for urban climate change mitigation and adaptation strategies: The case of Hungary. Energy and Buildings, 62, 475-485. https://doi.org/10.1016/ j.enbuild.2013.03.011

Intergovernmental Panel on Climate Change. (2012). Managing the risks of extreme events and disasters to advance climate change adaptation. A special report of the Intergovernmental Panel on Climate Change. Cambridge University Press.

Intergovernmental Panel on Climate Change. (2014). Climate change 2014: Synthesis report. https:// www.ipcc.ch/site/assets/uploads/2018/02/SYR_ AR5_FINAL_full.pdf

Intergovernmental Panel on Climate Change. (2018). Global warming of $1.5^{\circ} \mathrm{C}$ : Summary for policymakers. https://www.ipcc.ch/sr15/chapter/spm

Islam, M. S., Swapan, M. S. H., \& Haque, S. M. (2013). Disaster risk index: How far should it take account of local attributes? International Journal of Disaster Risk Reduction, 3, 76-87. https://doi.org/10.1016/ j.ijdrr.2012.10.001 
Jamshed, A., Birkmann, J., Feldmeyer, D., \& Rana, I. A. (2020). A conceptual framework to understand the dynamics of rural-urban linkages for rural flood vulnerability. Sustainability, 12(7), Article 2894. https:// doi.org/10.3390/su12072894

Kappes, M. S., Papathoma-Köhle, M., \& Keiler, M. (2012). Assessing physical vulnerability for multihazards using an indicator-based methodology. Applied Geography, 32(2), 577-590. https://doi.org/ 10.1016/j.apgeog.2011.07.002

Kloosterman, R. C., \& Lambregts, B. (2007). Between accumulation and concentration of capital: Toward a framework for comparing long-term trajectories of urban systems. Urban Geography, 28(1), 54-73. https://doi.org/10.2747/0272-3638.28.1.54

Kokkonen, T. V., Grimmond, C. S. B., Christen, A., Oke, T. R., \& Järvi, L. (2018). Changes to the water balance over a century of urban development in two neighborhoods: Vancouver, Canada. Water Resources Research, 54(9), 6625-6642. https://doi. org/10.1029/2017wr022445

Krellenberg, K., Höfer, R., \& Welz, J. (2011). Dinámicas recientes y relaciones entre las estructuras urbanas y socioeconómicas en Santiago de Chile: El caso de Peñalolén [Recent dynamics and relationships between urban and socio-economic structures in Santiago de Chile: The case of Peñalolén]. Revista de Geografía Norte Grande, 48, 107-131. https:// doi.org/10.4067/s0718-34022011000100007

Larondelle, N., Hamstead, Z. A., Kremer, P., Haase, D., \& McPhearson, T. (2014). Applying a novel urban structure classification to compare the relationships of urban structure and surface temperature in Berlin and New York City. Applied Geography, 53, 427-437. https://doi.org/10.1016/j.apgeog.2014.07.004

Lee, Y.-J. (2014). Social vulnerability indicators as a sustainable planning tool. Environmental Impact Assessment Review, 44, 31-42. https://doi.org/10.1016/ j.eiar.2013.08.002

Leichenko, R., McDermott, M., \& Bezborodko, E. (2015). Barriers, limits and limitations to resilience. Journal of Extreme Events, 2(1), Article 1550002. https://doi. org/10.1142/s2345737615500025

Li, Y., Schubert, S., Kropp, J. P., \& Rybski, D. (2020). On the influence of density and morphology on the urban heat island intensity. Nature Communications, 11(1), Article 2647. https://doi.org/10.1038/s41467020-16461-9

Li, Y., Zhang, X., Zhao, X., Ma, S., Cao, H., \& Cao, J. (2016). Assessing spatial vulnerability from rapid urbanization to inform coastal urban regional planning. Ocean \& Coastal Management, 123, 53-65. https://doi.org/ 10.1016/j.ocecoaman.2016.01.010

Lowry, J. H., \& Lowry, M. B. (2014). Comparing spatial metrics that quantify urban form. Computers, Environment and Urban Systems, 44, 59-67. https://doi. org/10.1016/j.compenvurbsys.2013.11.005

Malakar, K., \& Mishra, T. (2016). Assessing socio- economic vulnerability to climate change: A city-level index-based approach. Climate and Development, 9(4), 348-363. https://doi.org/10.1080/17565529. 2016.1154449

McPherson, E. G., Nowak, D., Heisler, G., Grimmond, S., Souch, C., Grant, R., \& Rowntree, R. (1997). Quantifying urban forest structure, function, and value: The Chicago urban forest climate project. Urban Ecosystems, 1, 49-61. https://doi.org/10.1023/a: 1014350822458

Mertz, O., Halsnæs, K., Olesen, J. E., \& Rasmussen, K. (2009). Adaptation to climate change in developing countries. Environmental Management, 43(5), 743-752. https://doi.org/10.1007/s00267-0089259-3

Mustafa, D. (2003). Reinforcing vulnerability? Disaster relief, recovery, and response to the 2001 flood in Rawalpindi, Pakistan. Global Environmental Change Part B: Environmental Hazards, 5(3/4), 71-82. https://doi.org/10.1016/j.hazards.2004.05.001

Nguyen, A. L., Dang, V. H., Bosma, R. H., Verreth, J. A. J., Leemans, R., \& De Silva, S. S. (2014). Simulated impacts of climate change on current farming locations of striped catfish (Pangasianodon hypophthalmus; sauvage) in the Mekong Delta, Vietnam. AMBIO, 43(8), 1059-1068. https://doi.org/10.1007/s13280014-0519-6

Nijman, J. (2007). Introduction-Comparative urbanism. Urban Geography, 28(1), 1-6. https://doi.org/ 10.2747/0272-3638.28.1.1

Novack, T., \& Stilla, U. (2014). Classification of urban settlements types based on space-borne SAR datasets. ISPRS Annals of the Photogrammetry, Remote Sensing and Spatial Information Sciences, 2(7), 55-60. https://doi.org/10.5194/isprsannals-ii-7-55-2014

O’Brien, K., Eriksen, S., Nygaard, L. P., \& Schjolden, A. (2007). Why different interpretations of vulnerability matter in climate change discourses. Climate Policy, 7(1), 73-88. https://doi.org/10.1080/14693062. 2007.9685639

Panthi, J., Aryal, S., Dahal, P., Bhandari, P., Krakauer, N. Y., \& Pandey, V. P. (2016). Livelihood vulnerability approach to assessing climate change impacts on mixed agro-livestock smallholders around the Gandaki River Basin in Nepal. Regional Environmental Change, 16(4), 1121-1132. https://doi.org/10.1007/ s10113-015-0833-y

Parsons, M., Glavac, S., Hastings, P., Marshall, G., McGregor, J., McNeill, J., Morley, P., Reeve, I., \& Stayner, R. (2016). Top-down assessment of disaster resilience: A conceptual framework using coping and adaptive capacities. International Journal of Disaster Risk Reduction, 19, 1-11. https://doi.org/10.1016/j.ijdrr. 2016.07.005

Qaisrani, A., Umar, M. A., Siyal, G. E. A., \& Salik, K. M. (2018). What defines livelihood vulnerability in rural semi-arid areas? Evidence from Pakistan. Earth Systems and Environment, 2(3), 455-475. https://doi. 
org/10.1007/s41748-018-0059-5

Quattrone, G., \& Zannou, A. (1998). Interdependence in social and territorial planning theories and sustainable development principles. In ESRA conference papers (ersa98p364). European Regional Science Association.

Reusswig, F., Becker, C., Lass, W., Haag, L., Hirschfeld, J., Knorr, A., Lüdeke, M. K. B., Neuhaus, A., Pankoke, C., Rupp, J., Walther, C., Walz, S., Weyer, G., \& Wiesemann, E. (2016). Anpassung an die Folgen des Klimawandels in Berlin-AFOK [Adaptation to the consequences of climate change in BerlinAFOK]. Senate Department for Environment, Traffic and Climate Protection. https://www.berlin.de/ sen/uvk/klimaschutz/anpassung-an-den-

klimawandel/programm-zur-anpassung-an-diefolgen-des-klimawandels

Reusswig, F., Hischl, B., \& Laas, W. (2014). Klimaneutrales Berlin 2050-Ergebnisse der Machbarkeitsstudie [Climate Neutral Berlin 2050-Results of the feasibility study] [Brochure]. Senate Department for Urban Development and Housing.

Roca Cladera, J., Marmolejo Duarte, C. R., \& Moix, M. (2009). Urban structure and polycentrism: Towards a redefinition of the sub-centre concept. Urban Studies, 46(13), 2841-2868. https://doi.org/10.1177/ 0042098009346329

Rößler, S., Wende, W., \& Krüger, T. (2014). Grundlagen für eine klimawandelangepasste Stadt- und Freiraumplanung [Foundations for urban and open space planning adapted to climate change]. REGKLAMRegionales Klimaanpassungsprogramm für die Modellregion Dresden.

Salas, J., \& Yepes, V. (2018). Urban vulnerability assessment: Advances from the strategic planning outlook. Journal of Cleaner Production, 179, 544-558. https:// doi.org/10.1016/j.jclepro.2018.01.088

Scheuer, S., Haase, D., \& Meyer, V. (2011). Exploring multicriteria flood vulnerability by integrating economic, social and ecological dimensions of flood risk and coping capacity: From a starting point view towards an end point view of vulnerability. Natural Hazards, 58(2), 731-751. https://doi.org/10.1007/ s11069-010-9666-7

Senate Department for Urban Development and Housing. (2011). Stadtentwicklungsplan Klima-Urbane Lebensqualität im Klimawandel sichern [Urban development plan climate-Safeguarding urban quality of life in the face of climate change] [Brochure]. https://www.stadtentwicklung.berlin.de/planen/ stadtentwicklungsplanung/download/klima/ step_klima_broschuere.pdf

Senate Department for Urban Development and the Environment. (2016a). 06.07 Urban structure. 06.08 Urban structure-Area types differentiated. https://www.stadtentwicklung.berlin.de/umwelt/ umweltatlas/e_text/eke607.pdf

Senate Department for Urban Development and the
Environment. (2016b). Stadtentwicklungsplan Klima KONKRET-Klimaanpassung in der wachsenden Stadt [Urban development plan Klima KONKRET-Climate adaptation in the growing city]. https://scnat.ch/de/id/cm4wq

Shah, A. A., Ye, J., Abid, M., Khan, J., \& Amir, S. M. (2018). Flood hazards: Household vulnerability and resilience in disaster-prone districts of Khyber Pakhtunkhwa province, Pakistan. Natural Hazards, 93(1), 147-165. https://doi.org/10.1007/ s11069-018-3293-0

Shrivastava, P. (2003). Principles of emergency planning and management. Risk Management, 5(2), Article 67. https://doi.org/10.1057/palgrave.rm.8240152

Solecki, W., Seto, K. C., Balk, D., Bigio, A., Boone, C. G., Creutzig, F., Fragkias, M., Lwasa, S., Marcotullio, P., Romero-Lankao, P., \& Zwickel, T. (2015). A conceptual framework for an urban areas typology to integrate climate change mitigation and adaptation. Urban Climate, 14, 116-137. https://doi.org/ 10.1016/j.uclim.2015.07.001

Somarakis, G., Stagakis, S., \& Chrysoulakis, N. (Eds.). (2019). ThinkNature: Nature-based solutions handbook. EU Horizon 2020.

Song, Y., \& Knaap, G.-J. (2004). Measuring urban form: Is Portland winning the war on sprawl? Journal of the American Planning Association, 70(2), 210-225. https://doi.org/10.1080/01944360408976371

Sorg, L., Medina, N., Feldmeyer, D., Sanchez, A., Vojinovic, Z., Birkmann, J., \& Marchese, A. (2018). Capturing the multifaceted phenomena of socioeconomic vulnerability. Natural Hazards, 92(1), 257-282. https://doi.org/10.1007/s11069-018-3207-1

Storch, H., \& Schmidt, M. (2008). Adaptation planning framework to climate change for the urban environment in Ho Chi Minh City. In A. Möller, B. Page, \& M. Schreiber (Eds.), Envirolnfo 2008: Proceedings of the 22nd International Conference Environmental Informatics-Informatics for environmental protection, sustainable development, and risk management (pp. 623-630). Shaker.

Theobald, D. M. (2001). Land-use dynamics beyond the American urban fringe. Geographical Review, 91(3), 544-564. https://doi.org/10.1111/j.19310846.2001.tb00240.x

Torrens, P. M., \& Marina, A. (2000). Measuring sprawl (CASA Working Papers 27). Centre for Advanced Spatial Analysis.

Turner, B. L., Kasperson, R. E., Matson, P. A., McCarthy, J. J., Corell, R. W., Christensen, L., Eckley, N., Kasperson, J. X., Luers, A., Martello, M. L., Polsky, C., Pulsipher, A., \& Schiller, A. (2003). A framework for vulnerability analysis in sustainability science. Proceedings of the National Academy of Sciences, 100(14), 8074-8079. https://doi.org/10.1073/pnas. 1231335100

Ward, H. C., \& Grimmond, C. S. B. (2017). Assessing the impact of changes in surface cover, human behaviour and climate on energy partitioning across 
Greater London. Landscape and Urban Planning, 165, 142-161. https://doi.org/10.1016/j.landurbplan. 2017.04.001

Wende, W., Huelsmann, W., Marty, M., Penn-Bressel, G., \& Bobylev, N. (2010). Climate protection and compact urban structures in spatial planning and local construction plans in Germany. Land Use Policy, 27(3), 864-868. https://doi.org/10.1016/ j.landusepol.2009.11.005

Weston, L. M. (2002). A methodology to evaluate neighbourhood urban form: A comparison to new urbanist principles. Planning Forum, 8, 64-77.

Wilson, W. J. (2010). Why both social structure and culture matter in a holistic analysis of inner-city poverty. The ANNALS of the American Academy of Political and Social Science, 629(1), 200-219. https://doi.org/ $10.1177 / 0002716209357403$

Wisner, B., Blaikie, P., Cannon, T., \& Davis, I. (2004). At risk: Natural hazards, people's vulnerability and disasters (2nd ed.). Routledge.

Wolf, T., \& McGregor, G. (2013). The development of a heat wave vulnerability index for London, United Kingdom. Weather and Climate Extremes, 1, 59-68. https://doi.org/10.1016/j.wace.2013.07.004

Xu, L., Cui, S., Tang, J., Nguyen, M., Liu, J., \& Zhao, Y. (2019). Assessing the adaptive capacity of urban form to climate stress: A case study on an urban heat island. Environmental Research Letters, 14(4), Article 044013. https://doi.org/10.1088/1748-9326/aafe27

Yoon, D. K. (2012). Assessment of social vulnerability to natural disasters: A comparative study. Natural Hazards, 63(2), 823-843. https://doi.org/10.1007/ s11069-012-0189-2

Zhao, M., \& Chen, Q. (2015). Risk-based optimization of emergency rescue facilities locations for large-scale environmental accidents to improve urban public safety. Natural Hazards, 75(1), 163-189. https://doi. org/10.1007/s11069-014-1313-2

Zhou, B., Rybski, D., \& Kropp, J. P. (2017). The role of city size and urban form in the surface urban heat island. Scientific Reports, 7(1), Article 4791. https://doi.org/ 10.1038/s41598-017-04242-2

\section{About the Authors}

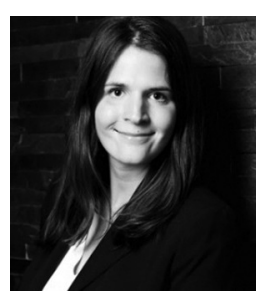

Angela Wendnagel-Beck holds a MSc in Geography and currently works as an academic staff member and is a PhD student at the Institute of Spatial and Regional Planning at University of Stuttgart. Her research focuses on dynamics of cities, assessment of urban climate change, and, in that context, the identification of risks and vulnerability. She also gives a seminar in GIS in Environmental and Regional Planning.

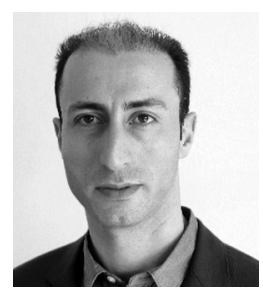

Marvin Ravan is a postdoctoral research fellow in the Institute of Spatial and Regional Planning at the University of Stuttgart. He did his PhD in disaster risk assessment methodology. His expertise falls in the area of disaster risk management and climate change adaptation, in particular developing vulnerability and risk assessment methodologies and tools. He is particularly interested in interdisciplinary research to enhance disaster resilience and climate adaptation in urban heritage, urban planning, and regional development.

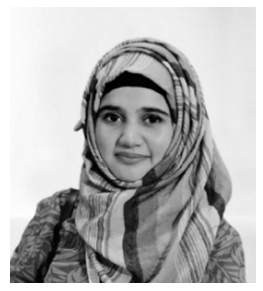

Nimra Iqbal is an urban and regional planner, currently working at the Institute of Spatial and Regional Planning, University of Stuttgart as academic staff member. She worked on Punjab Spatial Strategy, a World Bank project aimed at providing a spatial expression to provincial growth strategy in Punjab. Her research interests include assessment and modelling of dynamics of exposure and vulnerability to climate change in transforming urban regions, climate risk scenarios, and climate change adaptation.

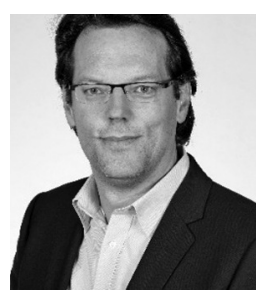

Jörn Birkmann, Prof. Dr.-Ing. habil., is director at the Institute of Spatial and Regional Planning of the University of Stuttgart. In addition to issues of planning and spatial governance, he has particularly worked in the area of vulnerability and risk research in the context of natural disasters and climate change in recent years. He is the coordinating lead author for the sixth assessment report of the IPCC, which will be presented to governments in October 2021. 


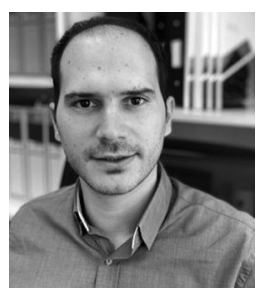

Giorgos Somarakis is a research fellow at FORTH (Foundation for Research and Technology) and a member of the RSLab (http://rslab.gr). He is a planning and regional development engineer and holds a PhD in the field of e-planning. His main research interests include spatial planning, sustainable development and resilience, climate change adaptation and mitigation, geographic information systems, decision support systems, and participatory decision-making. He has participated in various international and national research projects and has published his work in several scientific books, journals, and conference proceedings.

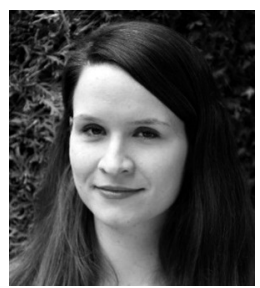

Denise Hertwig is a postdoctoral research fellow at the Department of Meteorology of the University of Reading, UK. She uses numerical modelling and experimental techniques to study a broad range of urban climate topics, including urban land-surface processes, air pollution exposure and heat emissions related to human activity, urban wind fields, and pollutant dispersion on local to city scales. She obtained her PhD in Meteorology from the University of Hamburg, Germany, working on boundarylayer wind-tunnel modelling of urban environments.

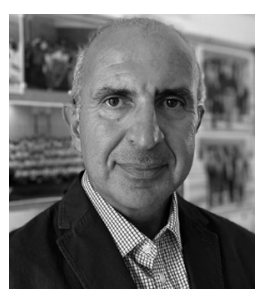

Nektarios Chrysoulakis, PhD, is a director of research at FORTH (Foundation for Research and Technology) and head of the RSLab (http://rslab.gr). He is co-principle investigator of the ERC-Synergy project urbisphere, focusing on coupling dynamic cities and climate. He is the coordinator of the H2020-Space project CURE, focusing on urban resilience. He has coordinated the projects URBANFLUXES (H2020), SEN4RUS (ERA.Net), BRIDGE (FP7), and GEOURBAN (FP7), and participated in several other projects. He is a visiting professor at the University of Crete and at the Mediterranean Agronomic Institute of Chania (CIHEAM-MAICh), with more than 250 publications.

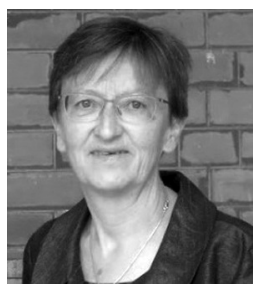

Sue Grimmond is met office joint chair and professor of urban meteorology at the University of Reading. She has been president of the International Association of Urban Climate (IAUC) and lead expert for the World Meteorological Organisation (WMO) on urban and building climatology. Her awards include Royal Meteorological Society Symons Gold Medal, Helmut E Landsberg Award (AMS), and Luke Howard Award (IAUC). Her research interests include measurement and modelling of cities and integrated urban hydro-meteorological, climate, and environmental services (IUS). 